\title{
ANALYSIS OF PROJECT IMPLEMENTATION SCHEDULE USING MICROSOFT PROJECT (Case Study: Trenggalek City Square Area)
}

\author{
Muhammad Zainal Muttaqin \\ Faculty of Engineering, Narotama University Surabaya \\ m.zainalmuttaqin07@gmail.com \\ Farida Hardaningrum \\ Faculty of Engineering, Narotama University Surabaya \\ farida.hardaningrum@narotama.ac.id
}

\begin{abstract}
A project implementation schedule can be said to be successful if the implementation process can be completed in accordance with the planned time. Planning a good project implementation schedule must be supported by good project control. Because what happens in the field is not necessarily in accordance with what has been planned. By analyzing the cost and end time of project completion, it can provide detailed project performance schedule information. In this study, the analysis of the project implementation schedule is done manually, which is to make the S curve and use the Microsoft Project 2019 program. The method used is to enter the data related to the analysis into the program, then this Microsoft project will calculate automatically according to the formulas. calculation formula that has been made, so that the calculation of the project implementation schedule analysis will be faster and more accurate. The results of the cost analysis following the price of the Trenggalek district work unit for the renovation of the City Square is IDR. 6,078,136,530. Estimated schedule in planning the S schedule time curve with Microsoft Project 2019, there is a time difference of scheduling 39 calendar days or a difference of 1 month more that can save time and costs of implementing work. At the planning stage of scheduling with an S curve of 20 weeks or 140 days, using Microsoft Project 2019, the results obtained 101 days of project completion time. In the area of ornamental plants experiencing critical trajectory, due to the end of the work that is expected to be completed and handover, so it must add workers to be on target.
\end{abstract}

Keyword: Project implementation schedule, Curve S, Microsoft Project 2019, Results of critical trajectories

\section{INTRODUCTION}

Trenggalek Regency has a moderate population growth. Urban population grew from 675,584 people to 691,295 people from 2010 to 2016 which is $2.27 \%$ growth. In response to this transformation, International Guide to Urban and Regional Planning (Guide) are intended to be a framework for improving global policies, plans, designs and implementation processes, which will make cities and regions more compact, socially inclusive and connected and better integrated and encourages sustainable urban development and resilient to climate change. Regional and spatial development cannot be separated because it is a unit that mutually supports one another. One aspect of environmentally friendly cities is the availability of green open space, this public space has always been a concern for the community, including children, people with disabilities and even the elderly. Green open space is part of the open space of an urban area filled with plants to support the ecological, social, cultural, economic and aesthetic benefits of green space can be classified according to their use. Green Open Space of the city square of Trenggalek, is expected to become a public space in the center of 
the city of Trenggalek, which is the concern of the people of Trenggalek city and people from outside the city, as a tourist destination because this square passes through provincial roads. Based on the background above the problem formulation is arranged as follows:

1. How is the analysis of the cost of developing Trenggalek City Square?

2. How is the schedule analysis needed to renovate Trenggalek City Square into a tourist area?

3. How to determine the critical path using Microsoft Project 2019?

\section{METHODOLOGY}

\section{Theoretical Basis}

Project is an activity carried out to achieve certain goals and objectives, which in the process is limited by the time and resources required and certain other requirements. Scheduling in the sense of a construction project is a tool to determine the activities needed to complete a project in a certain sequence and time frame, in which each activity must be carried out so that the project is completed on time at an economical cost (Callahan, 1992). Scheduling includes labor, materials, equipment, finance, and time. With proper scheduling, several types of losses can be avoided such as delays, cost overruns, and disputes. As for the steps in determining project scheduling is (Soeharto, 1999):

a. Work Breakdown Structure

b. Arranging the sequence of activities

c. Estimated period of time $\mathrm{d}$. Drafting schedule

According to Ervianto (2005:21), project management is all the planning, implementation, control, and coordination of a project from the beginning (idea) to the end of the project to ensure the project implementation on time, on cost and on quality. Each project has a specific goal, where each of these objectives there are basic limitations, namely the amount of the budgeted costs, the scheduled time and quality that must be met.

The S Curve is a graph developed by Warren T. Hanumm of observations of a large number of projects from the beginning to the end of the project. The $S$ curve can show the progress of the project based on the activities, time and work presented as a cumulative percentage of all project activities. Visualization of the $S$ curve can provide information about the progress of the project by comparing it to the planned schedule. From this it is known whether there is a project delay or acceleration.

Microsoft project 2019 is an application for managing a project. Microsoft project is a planning system that can help in scheduling a project or series of work. Microsoft project is also able to help record and monitor the use of resources, both in the form of human resources and in the form of equipment. What is done by the Microsoft Project include: recording labor needs in each sector, recording employee hours, overtime and calculating expenses related to labor costs, entering fixed costs, calculating total project costs, and helping control labor usage in several work to avoid overallocation. (overloaded on the use of hands) (Adi Kusrianto, 2008). 


\section{Research procedure}

Start

Literature review

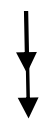

Formulation of the problem

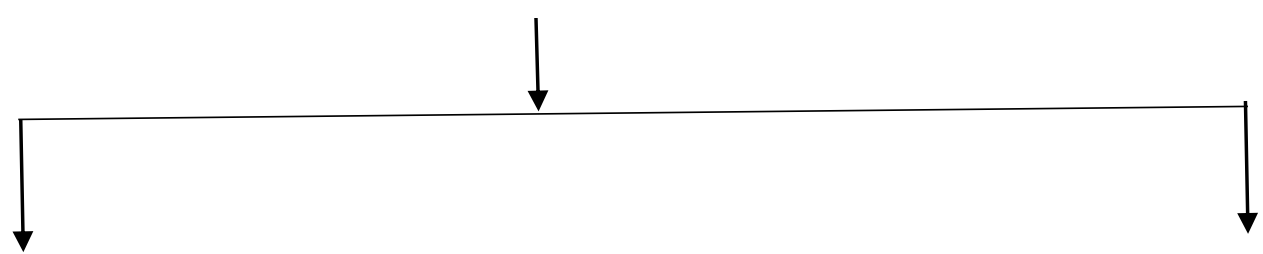

Primary data

1. Documentation Survey

2. Size of City

Secondary Data

Square Area

1. Bill of quantity (BQ)

2. DED Image

3.Techinical Spesification

Project Schedule Analysis using

Microsoft Project 2019

Knowing how long the time and Critical

Path in the Trenggalek City Square work

End

\section{Data collection}

Data collection methods used to collect data in this study using survey and documentation techniques. The data needed is primary data from location and secondary surveys, namely documentation from relevant agencies such as contractors, related agencies, and supervisory consultants. There are 2 variables in question:

a. Primary Data

Survey data of Trenggalek Regency City Square are as follows: North side: 148.73 meters, South side: 144.98 meters, West side: 117.71 meters, East side: 112.43 meters.

b. Secondary Data

Secondary data of this study were taken from the Trenggalek Regency PUPR Office, including: Bill of quantity (BQ) volume lists, Material price and wage ists, DED image, Technical specifications.

\section{Data analysis}

Data analysis was performed with the help of the Microsoft project 2019 program. By inputting data related to analysis into the program, this Microsoft project will automatically perform calculations in accordance with the calculation formulas that have been 
made by this program. The process of inputting data to analyze the concept of outcome values involves two stages:

a. Develop a project schedule plan (baseline)

b. Know the critical trajectory (Critical Tasks)

\section{Job load}

\section{RESULT AND DISCUSSION}

Job load $=$ Price per Job $/$ Total Price Amount $\times 100 \%$

(1) This is a recapitulation of the results of the calculation of the job load in the City Square of Trenggalek:

Table 1. The result of the load of the job

\begin{tabular}{ccc}
\hline NUMBER & DESCRIPTION & JOB LOAD \% \\
\hline I & PREPARATORY WORK & 1,576 \\
II & PEDESTRIAN AND PARKING WORK & 20,399 \\
III & VOCATIONAL WORK & 18,748 \\
IV & TRIBUN AREA WORK & 23,376 \\
V & ELECTRICAL UTILITY WORK & 15,440 \\
VI & OTHER WORK & 20,460 \\
& TOTAL & 100 \\
\hline
\end{tabular}

\section{Set the hours of work}

Step 1: Select Project Menu > Change Working Time

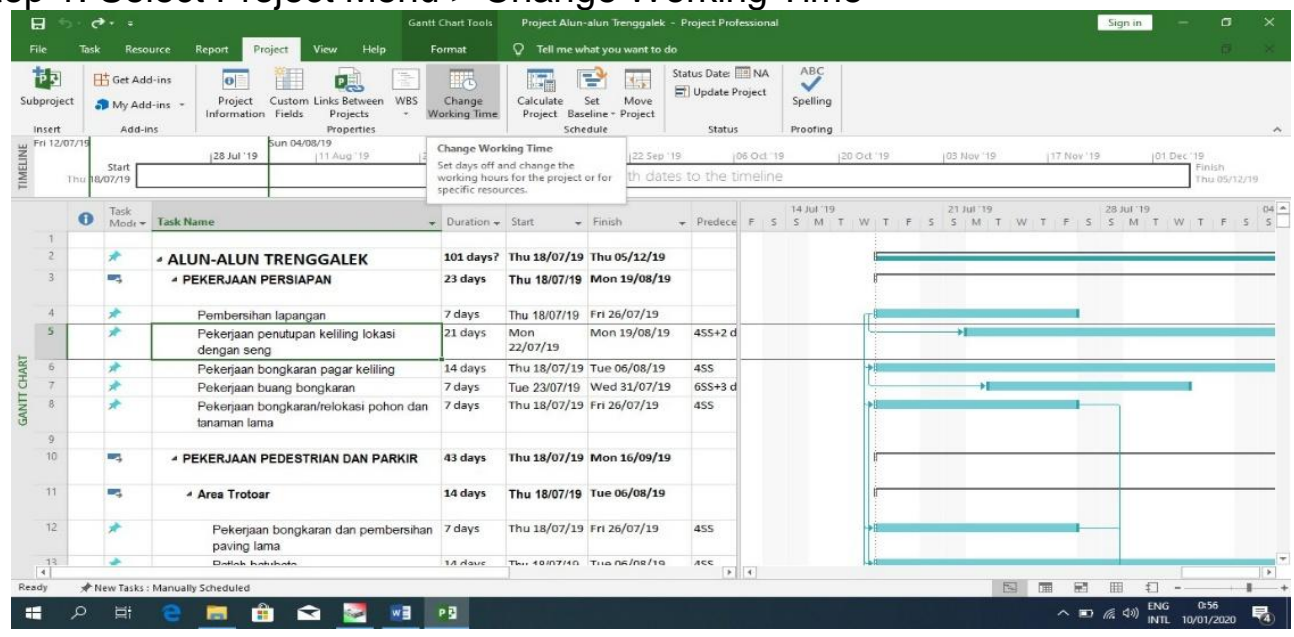

Figure 1. Step 1

Step 2: Create New Calendar > Create Name Change the Working Day of the Trenggalek

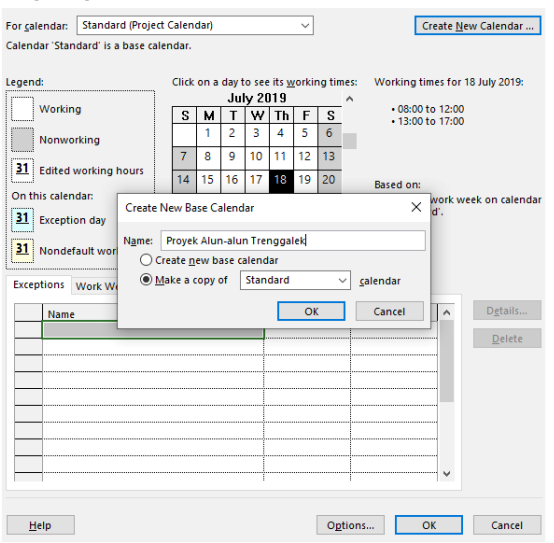


Figure 2. Step 2

Step 3: Work week > Set Hours - OK

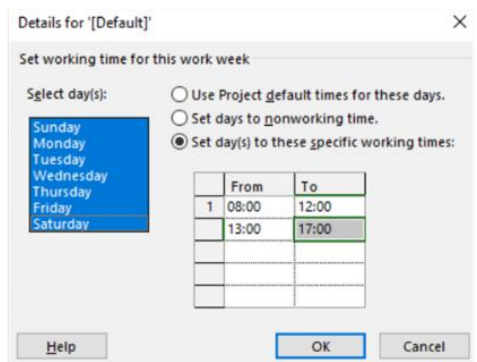

Figure 3. Step 3

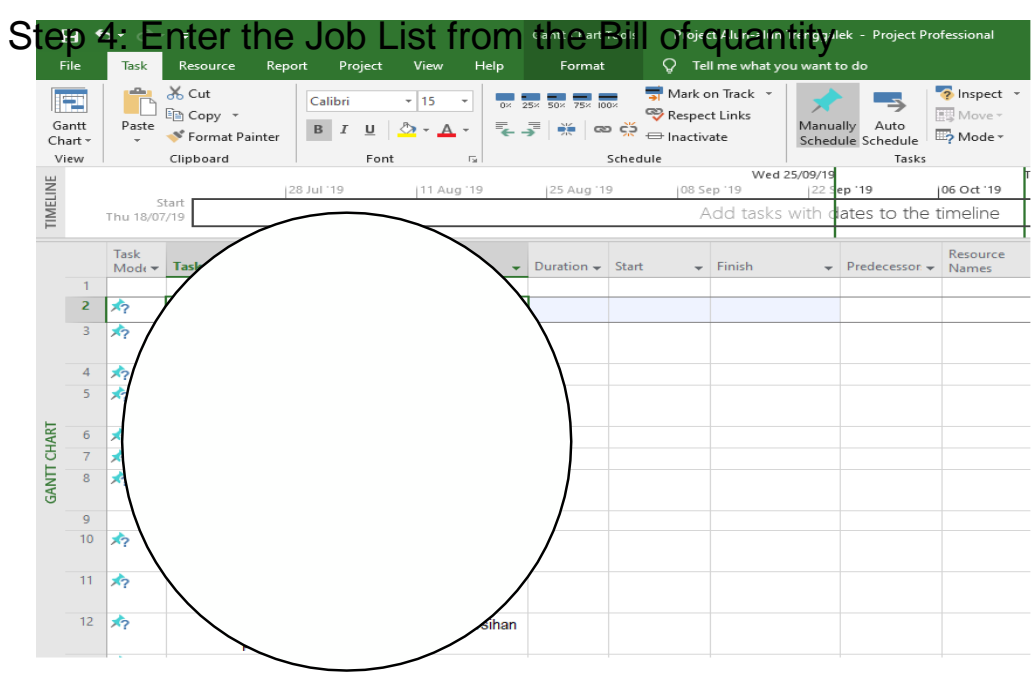

Figure 4. Step 4

\section{the duration of work}

Scheduling the start and end of an activity, many factors are considered, including the dependence of activities, limitations and holiday interruptions.

Duration $=$ Coefficient $x$ volume $/$ resource effort

a. Duration is the actual amount of time needed to complete an activity

b. The coefficient is the business value taken from the analysis on the price of the principal unit of activity to complete an activity

c. Resource effort is the amount of effort a resource is allocated to do the activity. 


\begin{tabular}{|c|c|c|c|c|}
\hline $\begin{array}{l}\text { Task } \\
\text { Mode }\end{array}$ & Task Name & Duratior - & Start & Finish \\
\hline-5 & $\triangle$ ALUN-ALUN TRENGGALEK & 101 days? & Thu $18 / 07 / 19$ & Thu 05/12/19 \\
\hline$=$ & $\triangle$ PEKERJAAN PERSIAPAN & 28 days & Thu $18 / 07 / 19$ & Mon 26/08/19 \\
\hline 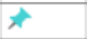 & Pembersihan lapangan & 7 days & Thu 18/07/19 & Fri $26 / 07 / 19$ \\
\hline 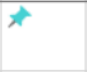 & $\begin{array}{l}\text { Pekerjaan penutupan keliling lokasi } \\
\text { dengan seng }\end{array}$ & 21 days & $\begin{array}{l}\text { Mon } \\
29 / 07 / 19\end{array}$ & Mon 26/08/19 \\
\hline$\star$ & Pekerjaan bongkaran pagar keliling & 14 days & Thu $18 / 07 / 19$ & Tue 06/08/19 \\
\hline$\star$ & Pekerjaan buang bongkaran & 7 days & Tue 23/07/19 & Wed $31 / 07 / 19$ \\
\hline$\star$ & $\begin{array}{l}\text { Pekerjaan bongkaran/relokasi pohon dan } \\
\text { tanaman lama }\end{array}$ & 7 days & Thu $18 / 07 / 19$ & Fri $26 / 07 / 19$ \\
\hline 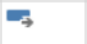 & $\triangle$ PEKERJAAN PEDESTRIAN DAN PARKIR & 43 days & Thu 18/07/19 & Mon 16/09/19 \\
\hline-9 & $\triangle$ Area Trotoar & 14 days & Thu $18 / 07 / 19$ & Tue 06/08/19 \\
\hline$\star$ & $\begin{array}{l}\text { Pekerjaan bongkaran dan pembersihan } \\
\text { paving lama }\end{array}$ & 7 days & Thu $18 / 07 / 19$ & Fri $26 / 07 / 19$ \\
\hline
\end{tabular}

Figure 5. Determine the duration of work

\section{Manage network planning}

There are 4 kinds of Task Relation in Ms. Project:

1. FS : Finish to Start

Work $B$ can start after Work $A$ is finished.

2. FF: Finish to Finish

Work $A$ and $B$ are completed simultaneously.

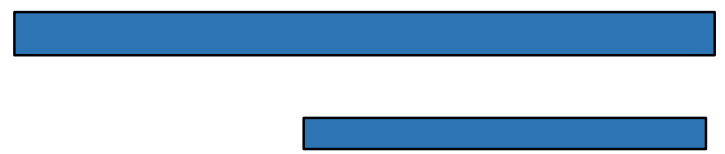

3. SS: Start to Start Work A and B begin together.

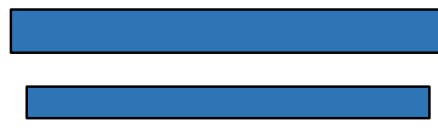

Figure 8. Start to Start

4. SF: Start to Finish

Job A can only be ended if job $B$ has started

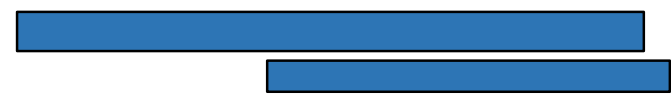

Figure 9. Start to Finish 


\subsection{Look for critical trajectories}

1. Format $>$ Critical Tasks

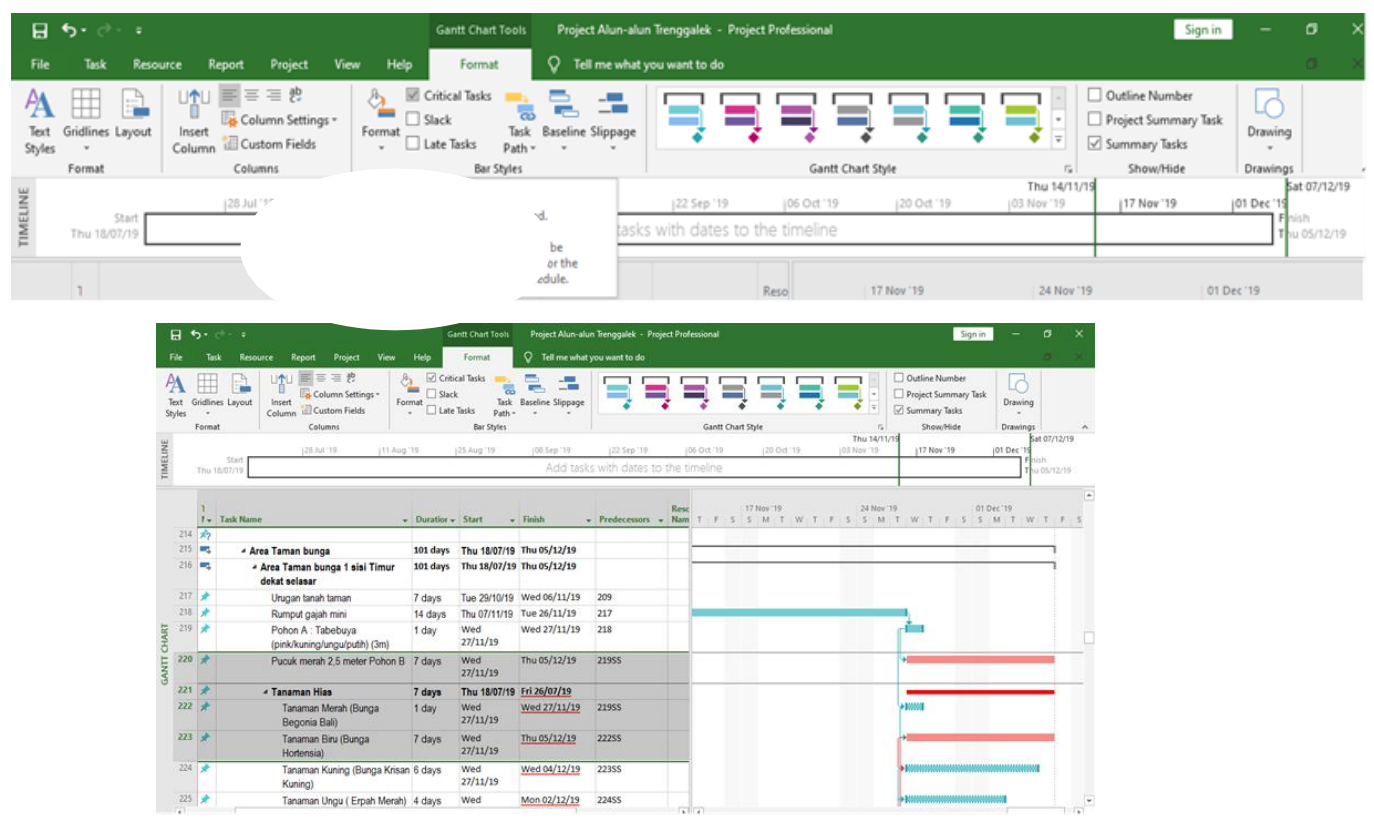

Figure 10. Format $>$ Critical Tasks

Comparison of the results of the S Curve schedule with the Microsoft project 2019

From the results of the analysis using the 2019 Microsoft Project application from the regional spatial planning project at Trenggalek City Square obtained the following results:

5. Currently the development of Trenggalek Regency Square has undergone a very rapid development process, some spots have begun to be renovated gradually in accordance with initial planning.

6. The planning stages of the $S$ curve is 20 weeks or 140 days, using Microsoft Project 2019 the results obtained 101 days of project completion time.

\section{CONCLUSIONS}

From the analysis of project implementation schedule of the Trenggalek City Square, the conclusions are as follows:

1. Unit price of Trenggalek Regency for renovation of City Square is about Rp. $6,078,136,530$

2. The results of the schedule analysis on the $S$ curve time schedule planning with the Microsoft project 2019, there is a time difference of scheduling 39 calendar days or a difference of 1 month that can save time and costs of implementing work. At the planning stage of scheduling with an S curve of 20 weeks or 140 days, when using Microsoft Project 2019 the results obtained 101 days of project completion time.

3. In the flower garden area near the lobby hall, ornamental plants include the planting of red plants of Bali begonia flowers, yellow plants of chrysanthemum, purple plants of red erpas, green plants and red coleus meana red tongue experiencing a critical trajectory, due to the end of the work expected to be completed and handover, so you have to add workers to be on target. To discuss implementation costs, . Furthure studies can be done .

\section{Recommendations}

Some recommendations in this research are as follows: 
1. For the price quote is expected to be below the initial plan or according to the specified budget.

2. Making relationships between work in the 2019 Microsoft project should be done carefully in order to obtain accurate analysis results.

3. In implementing a project, the scheduling and number of workers should be carried out.

4. Material, tools, labor and sub-contractor needs for each work item, so that their use is more efficient and can be identified what types of work are profitable / detrimental.

5. In this study the calculation of the project scheduling concept can be compared using the Microsoft project 2019 program.

6. For planning costs, implementation costs can be further studied using the 2019 Microsoft project program

\section{REFERENCES}

Abrar Husen (2009) Manajemen Proyek.

Adi Suryono (2007) Analisis Perencanaan Proyek Pembangunan Wisma Wali Santri Assalam Dengan

Microsoft Project 2003, Universitas Muhammadiyah Surakarta

Adinda Rezky (2018) Reschedulling Proyek Konstruksi Dengan Menggunakan Software Penjadwalan,

Universitas Islam Indonesia

Amanda.T Sanaky, Jermias Tjakra, A.K.T. Dundu (2015) Analisis Pengendalian Waktu Dan Biaya Pada Pekerjaan Konstruksi Dengan Menggunakan Microsoft Project 2010, Universitas Sam Ratulangi Manado

Budi Harsanto (2011) Manajemen Proyek Menggunakan Microsoft Project 2010

Dinas PUPR Kabupaten Trenggalek (2017) Prenecanaan Kawasan Alun-alun Kabupaten Trenggalek Kusrianto,Adi (2008) Panduan Lengkap Memakai Microsoft Project, PT Elex Media Komputindo Mitchel Danny Maximilian Pinontoan, Jantje Mangare (2015) Pengendalian Biaya dan Waktu Dengan

Metode Analisis Nilai Dan Hasil Dengan Microsoft Project 2010 (Studi Kasus : Gedung Mantop Tahap III), Universitas Sam Ratulangi Manado

Nurhayati (2010) Manajemen Proyek Ed.I, Graha IImu: Yogyakarta.

Sumaryani (2010) Analisis Konsep Nilai Hasil Pada Proyek Pembangunan Gedung Parkir Roda Dua Bertingkat 4 Lantai UMS Dengan Program Microsoft Project 2007. Universitas Sebelas Maret Surakarta.

Yuliana Jariah (2014) Pembuatan Penjadwalan Suatu Proyek Dengan Metode CPM

Wulfram Ervianto (2005) Manajemen Proyek Konstruksi. 